\title{
BONE HEALTH AND GROWTH IN SPINAL MUSCULAR ATROPHY TYPE 2 AND 3
}

\author{
SPINAL MÜSKÜLER ATROFi TIP 2 VE 3'TE KEMIK SAĞLIĞI VE BÜYÜME
}

\author{
Osman KIPOĞLU' (D), Esin KARAKILIÇ ÖZTURAN² (D), Orhan COŞKUN ${ }^{1}$, Ayşe Pınar ÖZTÜRK² (D), \\ Edibe PEMBEGÜL YILDIZ (D), Firdevs BAŞ² (D), Nur AYDINLI' ${ }^{1}$, Mine ÇALIŞKAN¹ (D)
}

'Istanbul University, Istanbul Faculty of Medicine, Department of Pediatrics, Division Pediatric Neurology, Istanbul, Turkey

${ }^{2}$ Istanbul University, Istanbul Faculty of Medicine, Department of Pediatrics, Division Pediatric Endocrinology, Istanbul, Turkey

ORCID IDs of the authors: O.K. 0000-0001-9208-6697; E.K.Ö. 0000-0002-8842-1752; O.C. 0000-0001-9229-404X;

A.P.Ö. 0000-0003-3466-2857; E.P.Y. 0000-0002-8016-0404; F.B. 0000-0001-9689-4464; N.A. 0000-0003-0492-3411; M.Ç. 0000-0002-6869-3937

Cite this article as: Kipoglu O, Karakilic Ozturan E, Coskun O, Ozturk AP, Yildiz Pembegul E, Bas F, et al. Bone health and growth in spinal muscular atrophy type 2 and 3. J Ist Faculty Med 2022;85(1):22-8. doi: 10.26650/IUITFD.884235

\section{ABSTRACT}

Objective: Spinal muscular atrophy is a lower motor neuron disease, but other parts of the body could be affected. This study compared bone mineral density with bone metabolism and physical growth rates in patients diagnosed with spinal muscular atrophy type 2 and type 3.

Materials and Methods: Twenty-six patients with spinal muscular atrophy were included in the study (15 patients for type 2 and 11 for type 3). Weights and heights of patients were measured, standard deviation scores were determined, and the body-mass index was calculated. Motor function and pubertal assessment were performed. Serum calcium, phosphorus, alkaline phosphatase, parathormone, and 25-hydroxyvitamin vitamin D levels were compared. Spine radiography for scoliosis and bone densitometry for bone mineral density were performed, and volumetric bone mineral density was calculated for age and sex.

Results: Medians of height standard deviation scores were significantly lower in type 2 patients. There was no difference between the two groups in terms of serum calcium, phosphorus, alkaline phosphatase, parathormone, and 25-hydroxyvitamin D levels. The ratio of scoliosis was higher in type 2 patients as was its severity, but Z-scores of volumetric bone mineral density was lower in the same group.

Conclusion: This study showed that bone mineralization and growth rates were significantly lower in spinal muscular atrophy, mainly in type 2. Further studies are needed to evaluate bone health in spinal muscular atrophy patients.

Keywords: Spinal muscular atrophy, bone mineral density, bone health

\section{ÖZET}

Amaç: Spinal müsküler atrofi, alt motor nöron hastalığıdır, ancak kemik sağlığı ve diğer birçok organ sistemi etkilenebilir. Bu çalışmada, tip 2 ve 3 spinal müsküler atrofi tanısı alan hastalarda kemik mineral yoğunluğu kemik metabolizması ve fiziksel büyüme oranları karşılaştırıldı.

Gereç ve Yöntemler: Çalışmaya spinal müsküler atrofisi olan 26 hasta dahil edildi (tip 2; 15, tip 3; 11 hasta). Hastaların ağırlıkları ve boyları ölçülerek standart sapma skorları belirlendi ve vücut kitle indeksi hesaplandı. Motor fonksiyon ve pubertal değerlendirme yapıldı. Serum kalsiyum, fosfor, alkalen fosfataz, parathormon ve 25-hidroksivitamin D seviyeleri karşılaştırıldı. Skolyoz için omurga radyografisi ve kemik mineral yoğunluğu için kemik dansitometrisi yapılarak yaş ve cinsiyete göre hacimsel kemik mineral yoğunluğu hesaplandı.

Bulgular: Tip 2 hastalarda medyan boy standart sapma skorları anlamlı olarak daha düşüktü. İki grup arasında serum kalsiyum, fosfor, alkalen fosfataz, parathormon ve 25-hidroksivitamin D seviyeleri açısından fark yoktu. Tip 2 hastalarda skolyoz oranı ve şiddeti daha yüksek, volümetrik kemik mineral yoğunluğu Z skoru daha düşüktü.

Sonuç: Bu çalışma, kemik mineralizasyonunun ve büyüme oranlarının, özellikle tip 2'de olmak üzere, spinal müsküler atrofide önemli ölçüde daha düşük olduğunu göstermiştir. Spinal müsküler atrofi hastalarında kemik sağlığını değerlendiren daha ileri çalışmalara ihtiyaç vardır.

Anahtar Kelimeler: Spinal müsküler atrofi, kemik mineral yoğunluğu, kemik sağlığı

Corresponding author/iletişim kurulacak yazar: osmankip@yahoo.com

Submitted/Başvuru: 21.02.2021 • Revision Requested/Revizyon Talebi: 26.04.2021 •

Last Revision Received/Son Revizyon: 28.04.2021 • Accepted/Kabul: 17.05.2021 • Published Online/Online Yayın: 04.01.2022 


\section{INTRODUCTION}

Low bone mineral density (BMD) and recurrent bone fractures are an important problems in spinal muscular atrophy (SMA) patients (1). Various mechanisms are responsible for these conditions. Immobility negatively affects bone mineralization and results in low BMD, osteopenia, and fractures $(2,3)$. Some studies on the relationship between the survival motor neuron (SMN) protein and osteoclast and bone remodeling have been published, but data on bone health and indicators of bone involvement in SMA patients remain limited (4). A recent study showed that bone resorptions and vertebral fractures increased in these patients and low levels of serum 25-hydroxyvitamin $D[25(\mathrm{OH}) \mathrm{D}]$ and high levels of parathormone $(\mathrm{PTH})$ were observed (5).

In our study, we aimed to assess and compare patients with SMA type 2 and type 3 in terms of bone mineral density, bone metabolism, fractures, localization and severity of scoliosis, growth, and pubertal features. To achieve this, both the volumetric method and biochemical analysis were used simultaneously to obtain reliable results about bone health, and as such our study will contribute to the literature.

\section{MATERIALS AND METHODS}

\section{Patients}

In this cross-sectional and single-centered study, 26 patients who had been followed up by the Department of Pediatric Neurology and diagnosed with SMA, including 15 patients of type 2 and 11 of type 3, were enrolled.

The inclusion criteria were defined as follows: 1) 18 months to 18 years of age; 2) clinically and genetically diagnosed as SMA type 2 and 3; 3) not having any chronic disease except for SMA; 4) not receiving any treatment that affects bone mineralization such as systemic steroids or bisphosphonates; 5) not suffering from congenital fractures. This study was approved by the Bioethics Committee of Istanbul University, Istanbul Faculty of Medicine (Date: 24.10.2019, No: 1213). Written informed consent was obtained from the parents.

\section{Endocrinologic assessment}

Height and weight were measured for all patients using a wall-mounted or infant scale calibrated Harpenden Stadiometer (Holtain Ltd.) and electronic scale (sensitivity of 0,1 $\mathrm{kg}$ ). If children could not stand, the length was measured from the heels to the top of the head, and weight was calculated by subtracting the parental weight from the total weight measured on the scale. An infant scale was used to weigh children under two years and when patients could not stand independently. Body mass index (BMI) was calculated as [weight (kilogram)/height (meter) ${ }^{2}$. According to national data, the standard deviation score (SDS) of all auxological measurements was calculated (6). Patients were categorized as obese (BMI SDS $>2$ ), overweight (BMI SDS between 1-2), normal-weight (BMI SDS between -2 and 1), and underweight (BMI SDS <-2) (7).

Marshall and Tanner's staging were used to assess puberty. The onset of puberty was defined as breast Tanner stage 2 in girls and testicular volume of $\geq 4 \mathrm{ml}$ in boys (8). The pubertal assessment was performed by a pediatric endocrinologist (EKO, APO, and FB). The rates of prepubertal and pubertal patients were determined in both groups, and volumetric bone mineral density (vBMD) was compared according to these two categories.

\section{Assessment of motor function}

The patients' motor function was evaluated according to the ability to perform the activities itemised in the Hammersmith Functional Motor Scale Expanded (HFMSE) test (9). For each item, if the patient was unable to complete it, the score was ' $O$ '. If achieved, the degree of success was scored as either ' 1 ' or ' 2 '. If all steps of the test were achieved, the total score was 66.

\section{Imaging of left hand and wrist and spine}

X-rays of the patients' left hands and wrists were taken. A single observer assessed bone age (BA) according to the Greulich Pyle Method (10).

X-rays of the whole spine anteroposterior (AP) and lateral views were performed to determine whether the patients had scoliosis. Concurring with the Scoliosis Research Society, patients were diagnosed with scoliosis if the curvature was more than $10^{\circ}$ Cobb's angle. The severity of each patient's scoliosis was determined in accordance with The International Scientific Society on Scoliosis Orthopedic and Rehabilitation Treatment (SOSORT) guideline in 2016 (11).

In an earlier study, the fastest progression of scoliosis had been shown to be around ten years of age (12). Thus, for assessing the relationship between scoliosis and age, we examined patients in two groups, under and above the age of ten.

Lateral thoracolumbar spine imaging was performed and reported by a single experienced reader to evaluate whether vertebral fracture was present.

\section{Evaluation of vitamin D status, bone mineral density, and osteoporosis}

Serum $[25(\mathrm{OH}) \mathrm{D}]$ concentrations were performed using the electro-chemiluminescence immunoassay (ECLIA) method (Cobas e601 autoanalyzer, Roche Diagnostic $\mathrm{GmbH}$, Mannheim, Germany). None of the patients were on vitamin D replacement, and samples were collected in the winter. Vitamin $D$ deficiency was defined as a serum [25(OH)D] level of $<12 \mathrm{ng} / \mathrm{mL}(<30 \mathrm{nmol} / \mathrm{L})$ and in- 
sufficiency as a level between 12 and $20 \mathrm{ng} / \mathrm{mL}$ (30-50 $\mathrm{nmol} / \mathrm{L})$. Levels higher than $20 \mathrm{ng} / \mathrm{mL}(50 \mathrm{nmol} / \mathrm{L})$ were accepted as sufficient (13).

The bone mineral density of $L 1$ to $L 4$ lumbar spine was measured either by a Lunar DPX $1 \mathrm{Q}$ with a pediatric software package or Hologic QDR 4500 (Hologic, Inc, Waltham, Mass) scanner. Hologic $₫$ Conversion Tables were used to switch from a Lunar DPX IQ to a Hologic densitometer (14). We calculated volumetric bone mineral density (VBMD) $\left(\mathrm{gram} / \mathrm{cm}^{3}\right)$ of patients using the formula of Carter et al. [Bone Mineral Content (BMC)/area ${ }^{1.5}$ (15). The vBMD Z-scores were calculated according to Turkish boys and girls of similar age using national data (16).

According to the International Society for Clinical Densitometry (ISCD) 2019 criteria, diagnosis of osteoporosis in children and adolescents should not be made based on densitometric criteria alone (17). Based on these criteria, we made a diagnosis of osteoporosis if the BMD Z-score was less than or equal to -2.0 with a history of significant clinical fracture, which was defined as one or more of the following: 1) $\geq 2$ fractures of long bone by ten years of age; 2) $\geq 3$ fractures of long bone at any age. Also, if patients had vertebral compression fractures, it was accepted to be diagnosed for osteoporosis.

\section{Statistical analysis}

The Statistical Package for the Social Sciences (SPSS) Statistic Base 21.0 (SPSS Inc., Chicago, IL) was used for statistical analysis. Shapiro-Wilk test was used for the evaluation of the distribution of variables. In the descriptive analysis, median; inter quarter range (IQR) are used when appropriate. Variables were compared with the Chi-squared test or Fisher's exact test where applicable. Student's t-test or Mann-Whitney U test was used to compare the continuous data between the two groups. P-value was considered as significant with $\leq 0.05$.

\section{RESULTS}

\section{Demographic data}

The median age of the patients was 7.2 (1.8-17.2) years in SMA type $2(n=15)$ and 7.7 (2.7-17.3) years in SMA type 3 $(n=11)$. The female/male ratio was $7: 8$ and $8: 3$ in type 2 and type 3 patients, respectively (Table 1). Median values of bone age were 6.0 and 8.0 years in type 2 and type 3 , respectively.

All patients in type 2 were non-ambulatory, and in type 3 one patient was non-ambulatory with the remainder being ambulatory.

\section{Anthropometric measurements and puberty}

The anthropometric parameters of our cohort are outlined in Table 1. Median of height SDS was significantly lower in type 2 ( $p=0.03$ ). Medians of BMI and weight SDS were not significantly different between the two groups $(p=0.64$ and 0.12 , respectively).
Both groups were compared in terms of puberty; six of 15 patients were pubertal in type $2(40 \%)$, five of 11 patients were pubertal in type 3 (45\%). The pubertal stages of the pubertal patients were compatible with their chronological age. Precocious or delayed puberty was not observed in either type. There were no significant differences in terms of pubertal features between the two groups $(p=0.91)$ (Table 1$)$.

\section{Motor function (HFMSE score)}

The median HFMSE score in SMA type 2 and type 3 patients was 9 and 46 , respectively $(p<0.01)$. HFMSE score was above 30 points in all patients except one in type 3 . In contrast, this score was below 30 in all patients except one in type 2.

\section{Laboratory analysis}

The serum levels of calcium (Ca), phosphorus (P), alkaline phosphatase (ALP), and parathormone (PTH) were within normal limits. Levels of serum $[25(\mathrm{OH}) \mathrm{D}]$ did not differ significantly between the two groups. The median serum level was $16.7 \mathrm{vs.} 17.3 \mathrm{ng} / \mathrm{ml}$ in type 2 and type 3 , respectively.

\section{Scoliosis}

Scoliosis was observed in $60 \%$ of patients in type 2 . Cobb's angle ranged from $45^{\circ}$ to $100^{\circ}$ in these patients, all of them classified as having severe or very severe scoliosis. Scoliosis (Cobbs angle $98^{\circ}$ ) was detected in only one patient in type 3 , this patient being the one who was non-ambulatory. Three patients that had spinal curvature between $0-9^{\circ}$ were not included in the scoliosis group.

Scoliosis was observed in all type 2 patients who were ten years of age or older; the frequency of scoliosis declined to $25 \%$ in patients between 5 and 10 years of age. No patient under five years of age had scoliosis in this group. According to Fisher's exact test, the differences between these three age groups in type 2 were considered significant ( $p=0.007$ ). The mean of Cobb's angle was $15^{\circ}$ and $76^{\circ}$ in patients who were $<10$ and $\geq 10$ years old, respectively. This difference was statistically significant $(p=0.004)$ (Table 2).

\section{Bone mineral density}

Z-scores of areal BMD were lower in type 2 patients $(p=0.018)$. In type 2 and type 3 patients, median vBMD $\left(\mathrm{gram} / \mathrm{cm}^{3}\right)$ was 0.065 and 0.087 , median Z-scores of vBMD were -2.6 , and -0.69 , respectively. These results were also statistically significant $(p=0.018$ and $p=0.03$, respectively) (Table 1).

\section{Osteoporosis and bone fractures}

None of the patients had a bone fracture history except one SMA type 2 patient who had a vertebral fracture. Thus, according to ISCD 2019 criteria, we had just one patient who fulfilled the criteria for osteoporosis. 
Table 1. Clinical and laboratory characteristics of patients with spinal muscular atrophy type 2 and 3 (Values are given as median and range (min-max))

\begin{tabular}{|c|c|c|c|}
\hline & Type $2(n=15)$ & Type $3(n=11)$ & $p$ value \\
\hline Gender (F/M) & $7 / 8$ & $8 / 3$ & \\
\hline Age (years) & $7.2(1.8-17.2)$ & $7.7(2.7-17.3)$ & $0.44^{\mathrm{a}}$ \\
\hline Weight SDS & $-1.7(-7.27-1.61)$ & $-0.06(-2.34-1.47)$ & $0.12^{\mathrm{a}}$ \\
\hline Height SDS & $-2.7(-7.25-0.85)$ & $-0.35(-4.6-0.35)$ & $0.03^{a}$ \\
\hline BMI SDS & $-0.44(-6.52-2.82)$ & $0.04(-1.8-1.77)$ & $0.64^{\mathrm{a}}$ \\
\hline BMI SDS groups & & & $0.32^{b}$ \\
\hline Normal (BMI SDS -2 - 1) & 8 & 8 & \\
\hline Overweight (BMI SDS 1-2) & 3 & 3 & \\
\hline Obese (BMI SDS >2) & 2 & - & \\
\hline Underweight (BMI SDS <-2) & 2 & - & \\
\hline $\begin{array}{l}\text { Pubertal stage (Tanner) } \\
\text { I } \\
\text { II-III-IV } \\
\text { V }\end{array}$ & $\begin{array}{l}9 \\
3 \\
3\end{array}$ & $\begin{array}{l}6 \\
2 \\
3\end{array}$ & $0.91^{\mathrm{b}}$ \\
\hline $\begin{array}{l}\text { Ambulation status } \\
\text { Non-ambulatory } \\
\text { Ambulatory }\end{array}$ & $\begin{array}{c}15 \\
-\end{array}$ & $\begin{array}{c}1 \\
10\end{array}$ & $<0.01^{c}$ \\
\hline HFMSE score (median) & 9 & 46 & $<0.01^{a}$ \\
\hline Scoliosis (Cobb's angle) & & & $0.013^{b}$ \\
\hline No scoliosis $\left(<10^{\circ}\right)$ & 6 & 10 & \\
\hline Severe, severe to very severe $\left(\geq 41^{\circ}-\leq 55^{\circ}\right)$ & 2 & 0 & \\
\hline Very severe $\left(\geq 56^{\circ}\right)$ & 7 & 1 & \\
\hline Number of fractures & 1 & 0 & \\
\hline $\operatorname{vBMD}\left(\mathrm{g} / \mathrm{cm}^{3}\right)$ & $0.065(0.033-0.182)$ & $0.087(0.071-0.149)$ & $0.018^{a}$ \\
\hline vBMD SDS & $-2.6(-6.1-10.0)$ & $-0.69(-2.3-3.6)$ & $0.03^{a}$ \\
\hline $\mathrm{Ca}(\mathrm{mg} / \mathrm{dL})$ (normal ranges: 9.2-11) & $9.8(9.4-10.9)$ & $10(9.4-10.2)$ & $0.72^{\mathrm{a}}$ \\
\hline$P(\mathrm{mg} / \mathrm{dL})$ (normal ranges: 3.2-5.8) & $4.7(3.5-6.0)$ & $4.9(3.3-6.1)$ & $0.61^{\mathrm{a}}$ \\
\hline ALP (U/L) (normal ranges: 70-270) & $130(63-205)$ & $145(40-200)$ & $0.5^{\mathrm{a}}$ \\
\hline 25-OH D (ng/mL) & $16.7(5.0-78.0)$ & $17.3(5.6-32.4)$ & $0.51^{\mathrm{a}}$ \\
\hline $\begin{array}{l}\text { Vit D status } \\
\text { Normal }(>20 \mathrm{ng} / \mathrm{mL}) \\
\text { Insufficiency }(12-20 \mathrm{ng} / \mathrm{mL}) \\
\text { Deficiency }(<12 \mathrm{ng} / \mathrm{mL})\end{array}$ & $\begin{array}{l}6 \\
7 \\
3\end{array}$ & $\begin{array}{l}4 \\
4 \\
3\end{array}$ & $0.61^{b}$ \\
\hline PTH $(\mathrm{pg} / \mathrm{mL})$ (normal range: $15-65)$ & $23.1(12.7-50.4)$ & $25(3.4-74.9)$ & $0.79^{a}$ \\
\hline
\end{tabular}

a: Mann-Whitney U Test, b: Chi Squared Test, c: Fisher's Exact Test, F: female, M: male, SDS: standard deviation score, BMI: body mass index, vBMD: volumetric bone mineral density, $\mathrm{g} / \mathrm{cm}^{3}$ : gram per cubic centimeter, Ca: calcium, P: phosphorus, ALP: alkaline phosphatase, 25-OH D: 25 dihydroxy vitamin D, PTH: parathormone, mg/dL: milligrams per deciliter, ng/mL: nanogram per milliliter, PTH: parathormone, $\mathrm{pg} / \mathrm{mL}$ : picogram per milliliter 
Table 2: Ratio of scoliosis and median of Cobb's angles in $<10$ and $\geq 10$ years old patients with SMA type 2

\begin{tabular}{|c|c|c|c|c|c|c|c|c|}
\hline \multirow[b]{2}{*}{ SMA type $2(n=15)$} & \multicolumn{3}{|c|}{ Ratio of scoliosis } & \multicolumn{5}{|c|}{ Cobb's angle } \\
\hline & $\mathrm{n}$ & $\%$ & $p$ value & $\begin{array}{c}\text { Median / } \\
\text { mean }\end{array}$ & $\begin{array}{l}\text { Std } \\
\text { dev }\end{array}$ & $\min$ & $\max$ & $p$ value \\
\hline$<10$ years old $(n=8)$ & 6 & 25 & \multirow{2}{*}{0.007} & $0^{\circ} / 15^{\circ}$ & 29.8 & $0^{\circ}$ & $78^{\circ}$ & \multirow{2}{*}{0.004} \\
\hline$\geq 10$ years old $(n=7)$ & 7 & 100 & & $75^{\circ} / 76^{\circ}$ & 10.8 & $47^{\circ}$ & $100^{\circ}$ & \\
\hline
\end{tabular}

SMA: spinal muscular atrophy, std dev: standard deviation, min: minimum, max: maximum

\section{DISCUSSION}

This study observed that bone density, height and vitamin $D$ levels were negatively affected, especially in type 2 patients. In addition, we observed that especially type 2 patients over the age of 10 had severe or very severe scoliosis. Therefore, bone health monitoring of SMA patients should be done carefully.

In a study conducted by Martinez et al., Z-scores of weights were between $\geq-2$ to $\leq 2$ in $81 \%$ of patients, regardless of SMA subtypes (18). Median Z-scores of height and BMI were -1.37 and 0.15 , respectively. The differences between type 2 and 3 were not specified. In our study, regardless of SMA subtypes, median SDS values of weight, height, and BMI were similar to those in Martinez et al.'s study $(-1.7,-1.2$, and 0.3 , respectively). Median SDS of weight and BMI were lower in type 2 patients; however, these differences were not statistically significant. Type 2 patients were shorter in height than type 3 patients; this situation could be explained by the higher severity of scoliosis in type 2 patients. It may be due to inadequate energy intake, and there is a need for further studies to yield this condition.

In our study, median chronological and bone age were 7.2 vs. 7.7 in type 2 patients and 6.0 vs. 8.0 in type 3 patients, respectively. We observed a strong positive correlation between chronological and bone age of all patients $(r=0.99, p<0.01)$. However, two patients in type 2 had a slightly lower bone age, and one patient in type 3 had a slightly higher bone age. This result showed that bone age is affected by chronological age rather than BMD.

In our study, six patients were pubertal (40\%) in type 2 and five patients (45.5\%) in type 3. No patient had precocious or delayed puberty. The median age and the rate of pubertal patients were similar in both subtypes of SMA. For this, the effects of puberty and chronological age on bone tissue mass and bone mineralization were homogeneous in both subtypes.

Vai et al. showed that serum calcium, phosphorus, and ALP levels were normal in 30 patients with SMA type 2 and 3. Also, the PTH levels were normal; however, two children had slightly higher levels than the normal limit (5). Similarly, Baranello et al. followed up 32 SMA type 2 and type 3 patients between the ages of 18 and 36 months in three visits. At each visit, they demonstrated that serum calcium, phosphorus, and ALP levels were normal (19). The Median levels of these laboratory tests were also normal in our study, and there was no significant difference between type 2 and 3 . The median PTH levels were $22.5 \mathrm{pg} / \mathrm{mL}$ and $33.5 \mathrm{pg} / \mathrm{mL}$ in type 2 and type 3 patients, respectively. This difference was not statistically significant.

Low levels of [25(OH)D] (below $20 \mathrm{ng} / \mathrm{mL}$ ) were shown in $36.6 \%$ of SMA patients by Vai et al. The frequency of Vitamin D insufficiency (below $20 \mathrm{ng} / \mathrm{mL}$ ) was higher in our patient group compared to other studies; levels of [25(OH)D] were below $20 \mathrm{ng} / \mathrm{mL}$ in 16 of 26 patients $(61.5 \%)$ and were normal (above $20 \mathrm{ng} / \mathrm{mL}$ ) in 10 patients. However, the median level was similar in both types of SMA, 16.32, $16.05 \mathrm{ng} / \mathrm{mL}$, respectively.

Scoliosis is a crucial problem that limits the quality of life in patients with SMA. Advancing age is a significant risk factor for the occurrence of scoliosis. Granata et al. showed that the mean age at the onset of scoliosis in SMA type 2 patients was 4.3 years, and this study showed that the frequency and severity of scoliosis increased by age (12). An annual increase of $>12^{\circ}$ degrees was observed in type 2 patients, and the fastest progression was at around ten years of age. In our study, we detected scoliosis in all type 2 patients above ten years of age. No patient under five years of age had scoliosis in type 2. A positive correlation between the severity of scoliosis and advancing age in SMA type 2 patients was observed; it was statistically significant $(r=0.749, p<0.01)$. Since only one patient with type 3 SMA had scoliosis, it is difficult to comment on the relationship between scoliosis and age in type 3 patients. Type 2 patients whose paraspinal muscles are weaker and exposed to body weight for a prolonged period with advanced age might suffer higher severity of scoliosis.

Bone mineral density is considered to be the standard method to assess bone quality (20). Wassermann et al. studied 85 patients with SMA. The mean Z-score of BMD of type 2 patients was lower than that in type 3 patients, 
-2.5 vs. -0.2 , respectively (21). The lowest mean Z-score of BMD was observed in type 1 patients. In contrast to Wassermann's report, in a study published in 2004 by Kinali et al., BMD was normal in all 12 SMA type 2 and 3 patients aged under 17 years (22). Both studies used areal BMD for bone mineralization. However, especially in children of growing age, areal BMD may not precisely be expressed by bone mineral content. VBMD was used to investigate bone mineral density in several clinical studies (23).

Baranello et al. performed bone mineral apparent density $(B M A D=v B M D)$ in 32 prepubertal SMA type 2 and 3 patients, and mean Z-scores of BMAD (vBMD) were -0.7 regardless of SMA subtypes at the beginning of the study (19). In our study, both groups were compared in terms of $\checkmark B M D$ and the Z-score of $v B M D$. Our cohort's median of $\checkmark B M D$ values were 0.065 and $0.087 \mathrm{gr} / \mathrm{cm}^{3}$, respectively, in type 2 and 3 patients. We corrected vBMD values according to age and sex and calculated the Z-score of vBMD for each patient. Median Z-scores of vBMD were -2.6 and -0.69 , respectively, in type 2 and 3 patients. These results showed that bone mineralization in SMA type 2 patients was lower in our cohort. The difference between type 2 and 3 patients was statistically significant.

In a prospective study conducted by Baranello et al., initial Z-scores of BMAD were below - 2 in $18 \%$ of patients, while this ratio was $37 \%$ at $36^{\text {th }}$ month. Our study found that this rate was $46.6 \%$, with the low BMD ratio being $66.6 \%$ in type 2 and $18.2 \%$ in type 3 . There was a positive correlation between chronological age and Z-score of $v B M D$ for the whole group $(r=0.47, p=0.015)$. A strong correlation was observed in type $3(r=0.755, p=0.007)$; no correlation was found in type 2 patients.

Boot et al. studied the effect of puberty on BMD in girls and boys. Five hundred children and adolescents were enrolled in this study, and age-corrected values were used. A positive correlation between puberty and vBMD was observed (24). We compared the bone density of prepubertal and pubertal SMA patients, and we found that the Z-score of vBMD increased by pubertal stages. Low bone mineral density (Z-score of $\mathrm{VBMD} \leq-2.0$ ) was observed in 7 of 9 prepubertal patients with type 2 (77.7\%) and 2 of 6 prepubertal patients with type 3 (33.3\%).

Wassermann et al. showed that Z-scores of BMD in non-ambulatory type 1 and 2 patients were lower than ambulatory type 3 patients. Similarly, in a study by Khatri et al. of 8 SMA patients, the Z-score of BMD was significantly lower in non-ambulatory SMA patients than in ambulatory (25). Our study found that the Z-score of vBMD was significantly lower in type 2 patients than in type 3 . The ambulation status of the patients could explain these results. All type 2 and only one type 3 patients with SMA were non-ambulatory in our cohort. Additionally, puberty and median age, which were considered to affect BMD, were similar in both groups. The HFMSE scores of patients were compatible with ambulation. The median of this score was significantly different between the groups.

Bone fractures are severe complications of SMA patients. In a recent study, the fracture rate in SMA type 2 patients was $46.9 \%$, and 38 of 81 patients had one or more fractures with various localization. This rate was $51.5 \%$ in SMA type $3 a$, and 17 of 33 patients had fractures (26). In our study, osteoporosis was diagnosed in only one patient who had a fracture of thoracic vertebrae.

The low number of patients included in our study is the most crucial limitation of our research. The patients who took part in our research all live in the same geographical area, and they are followed up by a single center. The results may not reflect the whole of society. Multicenter studies containing a large number of patients should be conducted. The volumetric method to evaluate BMD was used in our study, which gives it great strength given that some other methods for observing SMA type 2 patients who have severe scoliosis could be misleading for BMD.

\section{CONCLUSION}

Bone health is significantly affected to varying degrees in patients with SMA. We observed that type 2 patients were shorter in height than type 3. Serum Ca, P, ALP, and PTH levels were normal despite severe bone mineral deficiency; however, serum [25(OH)D] levels were lower in both types of patients. The ratio and severity of scoliosis increased by age in SMA type 2. Z-scores of VBMD were very low in patients with type 2 . The $\mathrm{VBMD}$ was correlated with Tanner stages, bone age, height, and weight. The main limitation of our study is that the number of patients is low. Studies involving more patients are needed.

Informed Consent: Written consent was obtained from the participants.

Ethics Committee Approval: This study was approved by the Clinical Research Ethical Committee of the Istanbul University, Istanbul Faculty of Medicine (Date: 24.10.2019, No: 1213).

Peer Review: Externally peer-reviewed.

Author Contributions: Conception/Design of Study- M.Ç., F.B., N.A., O.K., E.K.Ö.; Data Acquisition- A.P.Ö., O.C., O.K.; Data Analysis/Interpretation- E.P.Y., O.K.; Drafting Manuscript- O.K., E.K.Ö., A.P.Ö., O.C.; Critical Revision of Manuscript- M.Ç., F.B., N.A., E.P.Y.; Approval and Accountability- O.K., E.K.Ö., O.C., A.P.Ö., E.P.Y., F.B., N.A., M.Ç.

Conflict of Interest: Authors declared no conflict of interest

Financial Disclosure: Authors declared no financial support. 


\section{REFERENCES}

1. Shanmugarajan S, Swoboda KJ, lannaccone ST, Ries WL, Maria BL, Reddy SV. Congenital bone fractures in spinal muscular atrophy:functional role for SMN protein in bone remodeling. J Child Neurol 2007;22(8):967-73. [CrossRef]

2. Elias AN, Gwinup G. Immobilization osteoporosis in paraplegia. J Am Paraplegia Soc 1992;15(3):163-70. [CrossRef]

3. Donaldson CL, Hulley SB, Vogel JM, Hattner RS, Bayers JH, McMillan DE. Effect of prolonged bed rest on bone mineral. Metabolism 1970;19(12):1071-84. [CrossRef]

4. Shanmugarajan S, Tsuruga E, Swoboda KJ, Maria BL, Ries WL, Reddy SV. Bone loss in survival motor neuron (Smn-/SMN2) genetic mouse model of spinal muscular atrophy. J Pathol 2009;219(1):52-60. [CrossRef]

5. Vai S, Bianchi ML, Moroni I, Mastella C, Broggi F, Morandi L, et al. Bone and Spinal Muscular Atrophy. Bone 2015;79:11620. [CrossRef]

6. Neyzi O, Bundak R, Gökçay G, Günöz H, Furman $A$, Darendeliler F, Baş F. Reference values for weight, height, head circumference, and body mass index in Turkish children. J Clin Res Pediatr Endocrinol 2015;7(4):280-93. [CrossRef]

7. Cole TJ, Bellizzi MC, Flegal KM, Dietz WH. Establishing a standard definition for child overweight and obesity worldwide:International survey. BMJ 2000;320(7244):1240-3. [CrossRef]

8. Marshall WA, Tanner JM. Variations in pattern of pubertal changes in girls. Arch Dis Child 1969;44(235):291-303. [CrossRef]

9. O'Hagen JM, Glanzman AM, McDermott MP, Ryan PA, Flickinger J, Quigley J, et al. An expanded version of the Hammersmith Functional Motor Scale for SMA II and III patients. Neuromuscul Disord 2007;17(9-10):693-7. [CrossRef]

10. Greulich WW, Pyle SI. Radiographic atlas of skeletal development of the hand and wrist. Am J Med Sci 1959;238:393. [CrossRef]

11. Negrini S, Donzelli S, Aulisa AG, Czaprowski D, Schreiber S, Jean Claude de Mauroy, et al. 2016 SOSORT guidelines:Orthopaedic and rehabilitation treatment of idiopathic scoliosis during growth. Scoliosis Spinal Disord 2018;13:3. [CrossRef]

12. Granata C, Merlini L, Magni E, Marini ML, Stagni SB. Spinal muscular atrophy:Natural history and orthopaedic treatment of scoliosis. Spine (Phila Pa 1976) 1989;14(7):76062. [CrossRef]

13. Munns CF, Shaw N, Kiely M, Specker BL, Thacher TD, Ozono $\mathrm{K}$, et al. Global consensus recommendations on prevention and management of nutritional rickets. Horm Res Paediatr 2016;85(2):83-106. [CrossRef]
14. Hui SL, Gao S, Zhou XH, Johnston CC, Ying Lu, Glüer CC, Grampp S, et al. Universal Standardization of Bone Density Measurements: A Method with Optimal Properties for Calibration Among Several Instruments. J Bone Mineral Research 1997;12(9):1463-70. [CrossRef]

15. Carter DR, Bouxsein ML, Marcus R. New approaches for interpreting projected bone densitometry data. J Bone Miner Res 1992;7(2):137-45. [CrossRef]

16. Goksen D, Darcan S, Coker M, Kose T. Bone Mineral Density of Healthy Turkish Children and Adolescents. J Clin Densitom 2006;9(1):84-90. [CrossRef]

17. Weber DR, Boyce A, Gordon C, Högler W, Kecskemethy $\mathrm{HH}$, Misra M, et al. The Utility of DXA Assessment at the Forearm, Proximal Femur, and Lateral Distal Femur, and Vertebral Fracture Assessment in the Pediatric Population: 2019 ISCD Official Position. J Clin Densitom 2019;22(4):56789. [CrossRef]

18. Martinez EE, Quinn N, Arouchon K, Anzaldi R, Tarrant S, Ma NS, et al. Comprehensive nutritional and metabolic assessment in patients with spinal muscular atrophy:Opportunity for an individualized approach. Neuromuscul Disord 2018;28(6):512-9. [CrossRef]

19. Baranello G, Vai S, Broggi F, Masson R, Arnoldi MT, Zanin R, et al. Evolution of bone mineral density, bone metabolism and fragility fractures in Spinal Muscular Atrophy (SMA) types 2 and 3. Neuromuscul Disord 2019;29(7):525-32. [CrossRef]

20. Kranioti EF, Bonicelli A, Garcia-Donas JG. Bone-mineral density:clinical significance, methods of quantification and forensic applications. Res Reports Forensic Med Sci 2019;9:9-21. [CrossRef]

21. Wasserman HM, Hornung LN, Stenger PJ, Rutter MM, Wong BL, Rybalsky I, et al. Low bone mineral density and fractures are highly prevalent in pediatric patients with spinal muscular atrophy regardless of disease severity. Neuromuscul Disord 2017;27(4):331-7. [CrossRef]

22. Kinali M, Banks LM, Mercuri E, Manzur AY, Muntoni F. Bone mineral density in a paediatric spinal muscular atrophy population. Neuropediatrics 2004;35(6):325-8. [CrossRef]

23. Ott SM, O'Hanlan M, Lipkin EW, Newell-Morris L. Evaluation of vertebral volumetric vs. areal bone mineral density during growth. Bone 1997;20(6):553-6. [CrossRef]

24. Boot AM, de Ridder MA, Pols HA, Krenning EP, de Muinck Keizer-Schrama SM. Bone mineral density in children and adolescents:relation to puberty, calcium intake, and physical activity. J Clin Endocrinol Metab 1997;82(1):57-62. [CrossRef]

25. Khatri IA, Chaudhry US, Seikaly MG, Browne RH, lannaccone ST. Low bone mineral density in spinal muscular atrophy. J Clin Neuromuscul Dis 2008;10(1):11-7. [CrossRef]

26. Fujak A, Kopschina C, Forst R, Gras F, Mueller LA, Forst J. Fractures in proximal spinal muscular atrophy. Arch Orthop Trauma Surg 2010;130(6):775-80. [CrossRef] 